\title{
Ceramic Implantology: Boon or Bane in Implant Dentistry?
}

\section{Arpit Sikri ${ }^{*}$, SV Singh ${ }^{2}$, Jyotsana Sikri ${ }^{3}$ and Ruben Lobo ${ }^{4}$}

${ }^{1}$ Senior Lecturer, Department of Prosthodontics, Santosh Dental College and

Hospital, Santosh Deemed to be University, Ghaziabad, Delhi NCR, India

${ }^{2}$ Professor and Head, Department of Prosthodontics, Santosh Dental College and

Hospital, Santosh Deemed to be University, Ghaziabad, Delhi NCR, India

${ }^{3}$ Senior Lecturer, Department of Conservative Dentistry and Endodontics, Santosh

Dental College, Santosh Deemed to be University, Ghaziabad, Delhi NCR, India

${ }^{4}$ Head of Communications and Marketing, Dentist Channel Online Pvt Ltd, India

*Corresponding Author: Arpit Sikri, Senior Lecturer, Department of

Prosthodontics, Santosh Dental College and Hospital, Santosh Deemed to be

University, Ghaziabad, Delhi NCR, India.

Implants have been a gold standard treatment protocol for prosthetic rehabilitation in dental practices. Titanium and its alloys have ruled dental implantology since its initiation, harking back to the 1960s. As far as the clinical practice is concerned, many patients worry about the materials being exposed to their oral cavity and the effect this can have on their general wellbeing. While choosing dental implants, it is ideal to utilize the most un-receptive and least harmful material plausible. Throughout the long term, the pattern has been towards keeping away from the utilization of metals in our body. An elective material to titanium exists as ceramics explicitly zirconia for dental implants.

Dental implant is defined as any object or material such as an alloplastic substance or other tissue, which is partially or completely inserted or grafted into the body for therapeutic, diagnostic, prosthetic or experimental purposes (GPT 9). Since the 1960s, titanium dental implants have been the business standard. With many years of clinical achievement and development, titanium implants revolutionized both medicine and dentistry as a wonder material.

Zirconia implants are an option in disparity to titanium implants. They came into picture in the year 1987 and off lately picked up consideration with the expanding interest in the field of dentistry with a broader horizon. Currently, they are effectively examined with newer clinical exploration and research.

Zirconia dental implants are often showcased as a non-metal option in contrast to titanium implants. Zirconia (zirconium diox-
Received: November 21, 2020

Published: November 30, 2020

(C) All rights are reserved by Arpit Sikri., et

al. ide, $\mathrm{ZrO}_{2}$ ) is a white crystalline oxide of zirconium. It is polymorphic in nature, transforming its crystalline reticule from monoclinic (at room temperature) to tetragonal to cubic at increasing temperatures.

Focal points of Zirconia Dental Implants contrasted with Titanium includes 1 . Aesthetics - the colour tone of the dental implant makes it a material of choice particularly in rehabilitating the anterior or aesthetic zones. Titanium and alloys may lead to greyish discoloration due to the corrosion degradation products. This is unlike in case of ceramics as they oppose corrosion particularly galvanic corrosion. 2. Titanium or Metal Hypersensitivity - Allergy to titanium or different metals present in titanium inserts is one of the significant reasons patients look for treatment with metal free ceramic implants. With the period of time, literature has shown a number of hypersensitive issues in relation to metal (titanium) implants. This is quite uncommon in case of ceramic implants. 3. Soft tissue friendly nature- Ceramic implants are known to have a soft tissue friendly nature since it leads to lower accumulation of plaque around the dental implant.

Weaknesses of Zirconia Dental Implants as juxtaposed with Titanium include 1 . Longevity issues there has been a concern over the implications and complications of ceramic implants. Unlike, titanium as an implant material, both the immediate and cumulative survival rate of ceramics in implantology is questionable. 2. Ceramic fractures - as per the evidence based literature, there has been 
a potential concern over the mechanical properties of ceramic primarily strength and fracture resistance. Zirconia implants particularly with a small diameter are brittle as compared to the titanium dental implants. 3. Not a pragmatic treatment protocol for full mouth reconstructions, complex prosthetic rehabilitations as well as implant overdentures. Due to limited variety of implant designs and associated components, there is always a narrow spectrum of treatment approaches with ceramics in implant dentistry.

Ceramic dental implants are not a substitution for titanium implants, but rather an incredible option in a scope of cases. Interestingly, they can address the issues of a patient inclination for $100 \%$ free of metal, with the tasteful consolation of a white tone. A very common question still exists in the minds of dental surgeons as well as patients i.e. "Are Ceramic Dental Implants Better than Titanium?" Well, keeping in view the advantages superseding the disadvantages, the ceramic dental implants will prove to be the future of implant dentistry. However, furthermore research is needed to prove and solve this query totally [1-5].

\section{Bibliography}

1. Payer M., et al. "All-ceramic restoration of zirconia two-piece implants-a randomized controlled clinical trial". Clinical Oral Implants Research 26 (2015): 371-376.

2. Roehling S., et al. "A retrospective clinical study with regard to survival and success rates of zirconia implants up to and after 7 years of loading". Clinical Implant Dentistry and Related Research 18.3 (2015): 545-558.

3. Spies BC., et al. "Alumina reinforced zirconia implants: 1-year results from a prospective cohort investigation". Clinical Oral Implants Research 27.4 (2015): 481-490.

4. Furhauser R., et al. "Evaluation of soft tissue around singletooth implant crowns: the pink esthetic score". Clinical Oral Implants Research 16 (2005): 639-644.

5. Jung RE., et al. "Systematic review of the survival rate and the incidence of biological, technical, and aesthetic complications of single crowns on implants reported in longitudinal studies with a mean follow-up of 5 years". Clinical Oral Implants Research 23 (2012): 2-21.

\section{Assets from publication with us}

- Prompt Acknowledgement after receiving the article

- Thorough Double blinded peer review

- Rapid Publication

- Issue of Publication Certificate

- High visibility of your Published work

Website: $\underline{w w w}$.actascientific.com/

Submit Article: www.actascientific.com/submission.php

Email us: editor@actascientific.com

Contact us: +919182824667 